\author{
Marieta ŠOLTÉSOVÁ ${ }^{1}$, Michal PUŠKÁR ${ }^{2}$ \\ Supervisor: Michal PUŠKÁR² \\ DOI: https://doi.org/10.53052/9788366249851.08
}

\title{
ŚLAD EMISJI POJAZDÓW W ŚRODOWISKU
}

\begin{abstract}
Streszczenie: W artykule omówiono problem emisji pojazdów, biorąc pod uwagę obowiązujące limity emisji oraz procedurę certyfikacji, które były głównymi przyczynami tzw. afery "dieselgate". Celem niniejszego artykułu jest analiza emisji wybranych pojazdów przy użyciu różnych metodologii pomiarowych oraz porównanie otrzymanych wyników. W końcowej części pracy, przedyskutowano wpływ emisji pojazdów na środowisko.
\end{abstract}

Słowa kluczowe: pojazd, emisja, środowisko

\section{EMISSION FOOTPRINT OF VEHICLES IN RELATION TO ENVIRONMENT}

\begin{abstract}
Summary:
This paper deals with the questions of vehicle emissions, taking into consideration the valid emission limits and certification procedure, which were the main causes of the known "dieselgate" affair. The aim of this article is emission analysis of the selected vehicles using different measurement methodologies as well as comparison of the obtained results. Finally, the article discusses an impact of vehicle emissions on the environment.
\end{abstract}

Keywords: vehicle, emission , environment

\section{Introduction}

Testing of the vehicles in Europe using the Portable Emissions Measurement Systems indicated already from the year 2007 an unfavorable fact that the light diesel engine vehicles, certified according to the standard Euro 4, 5 and 6, are producing several times more $\mathrm{NO}_{\mathrm{X}}$ emissions than it is permitted by the corresponding emission limits [1-3]. This exceeding of the limits was caused due to several failures occurring in the approval procedures, namely due to low-level values of the vehicle acceleration and

1 Technical University of Košice, Faculty of mining, ecology, process control and geotechnologies, Institute of Earth resources, Department of geo and mining tourism, email: marieta.soltesova@tuke.sk

${ }^{2}$ Technical University of Kosice, Faculty of Mechanical Engineering, Department of Machine Design and Transport Engineering; michal.puskar@tuke.sk 
the narrow temperature range (from 20 to $30{ }^{\circ} \mathrm{C}$ ) applied during the NEDC certification [4-6]. Nowadays these problems are solved by means of the Worldwide harmonized Light vehicles Test Procedure (WLTP) and the supplementary test RealDriving Emissions (RDE). The analysis presented in this article includes 10 passenger motorcars tested by means of the NEDC under the laboratory conditions and on various routes in real transport. This presented research offers an alternative solution how to verify the vehicles and it enables identification of such vehicles that require a deeper evaluation of their capability.

\section{Experimental methods and results}

There were applied together 10 passengers cars in the role of experimental models, whereby three cars were equipped with the gasoline engines conforming to the emission standard Euro 5 and another seven cars were the diesel engine vehicles conforming to the standards Euro $4 \div 6$ (Fig. 1-2). All the laboratory tests and also the road traffic tests are standardly performed using the customary fuels that are in accordance with the European Direction 2009/30/EU as well as according to the specifications defined by the automobile producer. The laboratory emission tests were realised on a testing stand and the $\mathrm{NO}_{\mathrm{X}}$ and $\mathrm{CO}_{2}$ emissions were determined with an analyser [7]. Measuring of the $\mathrm{NO}_{\mathrm{X}}$ and $\mathrm{CO}_{2}$ emissions in the case of the real road traffic was performed by means of the Portable Emissions Measurement System. The ambient temperature was measured at $1 \mathrm{~Hz}$ and the atmospheric probe is an integrated part of the measuring equipment. The momentary values of the $\mathrm{NO}_{\mathrm{X}}$ and $\mathrm{CO}_{2}$ emissions on terms of the real traffic are calculated according to the Direction 2016/427 (EU, 2016) with the frequency $1 \mathrm{~Hz}$, using multiplication of the polluting substance concentrations by the mass flow of exhaust gases.

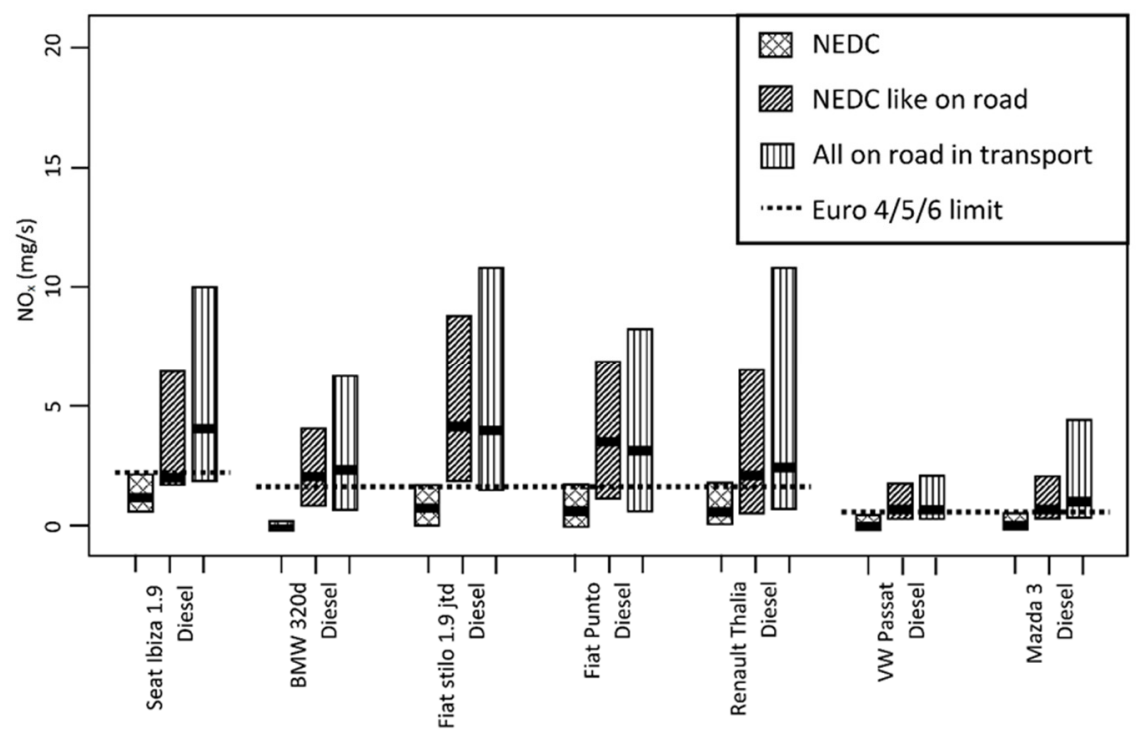

Figure 1. The column graphs of the $N O_{X}$ emissions $(\mathrm{mg} / \mathrm{s})$ for diesel vehicles 


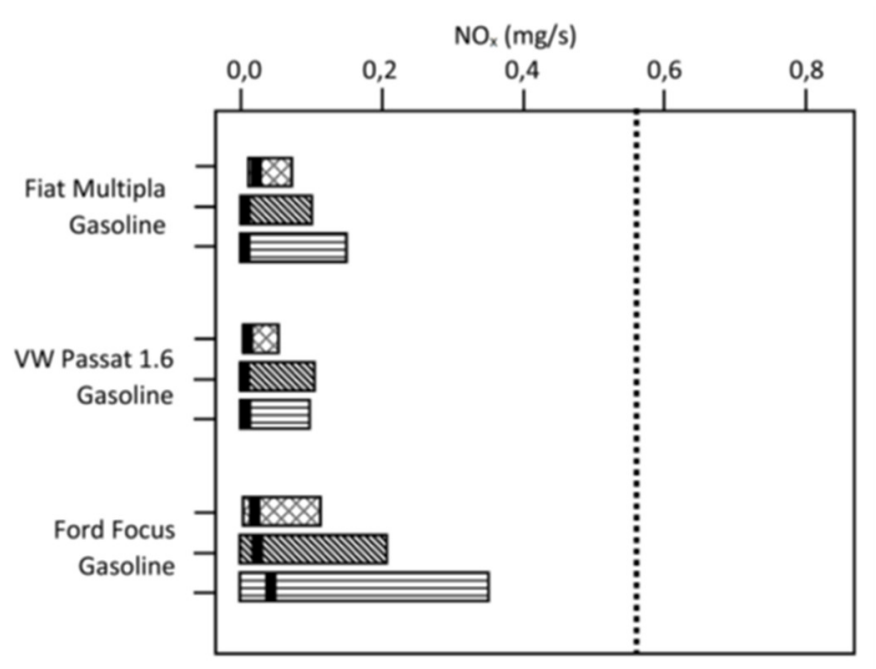

Figure 2. The column graphs of the $\mathrm{NO}_{X}$ emissions $(\mathrm{mg} / \mathrm{s})$ for gasoline vehicles

\section{Discussion}

It is possible to claim that the vehicles equipped with the diesel engines and gasoline engines have a tendency to fulfil the requirements of the corresponding emission standards in the case of the NEDC testing. The $\mathrm{NO}_{\mathrm{X}}$ emission values $(\mathrm{mg} / \mathrm{s})$ of the diesel vehicles are presented in Fig. 1 using the column graphs and the $\mathrm{NO}_{\mathrm{X}}$ emission values $(\mathrm{mg} / \mathrm{s})$ of the gasoline vehicles are given in Fig. 2 analogically. It is evident from the column graphs presented in Fig. 1 that most of the momentary $\mathrm{NO}_{\mathrm{X}}$ emission values of all vehicles are situated below the emission limit during the NEDC testing (Fig. 3, the left columns in graphs). This fact corresponds to the above-mentioned statement. However, there are recorded significant differences in the case of data obtained on the road, because in this situation most of the momentary diesel engine emission values are highly exceeding the emission limit (Fig.1, the right columns in graphs). The on road $\mathrm{NO}_{\mathrm{X}}$ emission values of the gasoline engines are also higher than the NEDC emissions, but they are always below the emission limit. If there are selected only driving conditions similar to NEDC, so the graphs (median values) mostly overlap the NEDC fields (Fig.2, the middle columns in graphs). This part of the analysis indicates a significantly different behaviour of the diesel vehicles during the NEDC testing in comparison with the drives on road using conditions similar to certification procedure.

\section{Conclusions}

The tested vehicles equipped with the diesel engines officially fulfil the emission standards Euro $4 \div 6$, however they are markedly exceeding the $\mathrm{NO}_{\mathrm{X}}$ emission limits during real traffic drives (i.e. the so-called on-road $\mathrm{NO}_{\mathrm{X}}$ emissions). A quite different 
situation is monitored in the case of the gasoline vehicles because their on-road $\mathrm{NO}_{\mathrm{X}}$ emissions remain under the valid limit. The presented conclusions clearly demonstrate a fact that the vehicles equipped with the gasoline engines have much smaller impact on environmental pollution and there are still existing possibilities to improve them in order their efficiency will be closer to the efficiency level of the diesel driving units.

\section{Acknowledgement:}

The article was written in the framework of Grant Projects: VEGA 1/0318/21 "Research and development of innovations for more efficient utilization of renewable energy sources and for reduction of the carbon footprint of vehicles" and KEGA 006TUKE-4/2020 "Implementation of Knowledge from Research Focused on Reduction of Motor Vehicle Emissions into the Educational Process."

"This work was supported by the Slovak Research and Development Agency under the Contract no. APVV-19-0328."

\section{REFERENCES}

1. PENG GENG, QINMING TAN, CHUNHUI ZHANG, LIJIANG WEI, KAI JIANG : Experimental investigation on NOx and green house gas emissions from a marine auxiliary diesel engine using ultralow sulfur light fuel, Science of The Total Environment, Volume 572, 1 December 2016, Pages 467-475

2. HIROYUKI YAMADA, RUMIKO HAYASHI, KENICHI TONOKURA: Simultaneous measurements of on-road/in-vehicle nanoparticles and NOx while driving: Actual situations, passenger exposure and secondary formations, Science of The Total Environment, Volumes 563-564, 1 September 2016, Pages 944-955

3. SIMMONS W.A., SEAKINS P.W.: Estimations of primary nitrogen dioxide exhaust emissions from chemiluminescence NOx measurements in a UK road tunnel, Science of The Total Environment, Volume 438, 1 November 2012, Pages 248-259

4. FAMELI K.M., ASSIMAKOPOULOS V.D.: Development of a road transport emission inventory for Greece and the Greater Athens Area: Effects of important parameters, Science of The Total Environment, Volume 505, 1 February 2015, Pages 770-786

5. XIANGYU FENG, YUNSHAN GE, CHAOCHEN MA, JIANWEI TAN, XIN WANG: Experimental study on the nitrogen dioxide and particulate matter emissions from diesel engine retrofitted with particulate oxidation catalyst, Science of The Total Environment, Volume 472, 15 February 2014, Pages 56-62

6. PUŠKÁR M., BRESTOVIČ T., JASMINSKÁ N. Numerical simulation and experimental analysis of acoustic wave influences on brake mean effective pressure in thrust-ejector inlet pipe of combustion engine. In: International Journal of Vehicle Design. Vol. 67, no. 1 (2015), p. 63-76. - ISSN 0143-3369

7. SINAY, J. et al. (2014) Multiparametric Diagnostics of Gas Turbine Engines. The Transactions of RINA, Vol 156, Part A2, International Journal of Maritime Engineering, 2014, p. 149-156, ISSN 1479-8751 